\title{
Chronic hepatitis $C$ virus infection in children and adolescents: Epidemiology, natural history, and assessment of the safety and efficacy of combination therapy
}

\author{
This article was published in the following Dove Press journal: \\ Adolescent Health, Medicine and Therapeutics \\ 4 October 2010 \\ Number of times this article has been viewed
}

\section{Giuseppe Indolfi \\ Elisa Bartolini \\ Davide Casavola \\ Massimo Resti}

Department of Sciences for Women and Child's Health, Liver and Pediatric Unit, Anna Meyer Children's Hospital, University of Florence, Florence, Italy
Correspondence: Giuseppe Indolfi Department of Sciences for Women and Child's Health, University of Florence, Viale Pieraccini 24, I-50139, Florence, Italy Tel +39-055-5662542

Fax+39-055-570380

Email g.indolfi@meyer.it
Abstract: Hepatitis $\mathrm{C}$ virus (HCV) is the most common cause of chronic liver disease of infectious etiology in children. Most of the children infected with HCV are asymptomatic, and only a few of them develop signs and symptoms of end-stage liver disease early in life. It is not possible to predict either in which patients HCV infection will have a bad outcome or the critical time in early adulthood when disease progression will accelerate. The experiences with therapy in children with chronic hepatitis $\mathrm{C}$ are based on earlier and continuing data from adult trials. The currently recommended treatment for chronic HCV infection in adults is the combination of peginterferon- $\alpha$ and ribavirin. The choice of this regimen is based on the results of randomized clinical trials that demonstrated the superiority of this combination treatment over standard interferon- $\alpha$ and ribavirin. Recently, results of pivotal, multicenter, interventional open-label studies on combined treatment with peginterferon- $\alpha$ and ribavirin in children have been published, and the US Food and Drug Administration and the European Medicines Agency have approved the combination therapy in those older than 3 years. The aim of this review is to evaluate critically the available data regarding the safety and efficacy of combination treatment with peginterferon- $\alpha$ and ribavirin in children.

Keywords: treatment, peginterferon, ribavirin, adverse events, sustained viral response

\section{Introduction}

Hepatitis C virus (HCV), discovered in 1989, ${ }^{1,2}$ is a single-stranded ribonucleic acid (RNA) virus and is a member of the genus Hepacivirus in the family Flaviviridae. ${ }^{3}$ The most characteristic feature of the HCV genome is the rapid evolution with genetic diversity and variation. Comparison of nucleotide sequences of variants recovered from infected individuals from different geographical regions revealed the existence of at least six major genetic types of HCV among a total of more than 50 genotypes identified worldwide. ${ }^{3}$ Each genotype shows more than $20 \%$ difference at the nucleotide level and more than $15 \%$ difference at the amino acid level compared with any of the other genotypes. ${ }^{3}$ Within each genetic group of HCV, a series of more closely related subtypes with 5\%-8\% diversity in nucleotide sequences and $4 \%-5 \%$ diversity in amino acid sequences were identified. In individual with chronic infection, HCV evolves under the pressure of the immune system and is present in many distinct phylogenetically related variants defined as quasispecies. The average diversity in nucleotide sequences among quasispecies is $0.9 \%{ }^{3}$ 
$\mathrm{HCV}$, together with hepatitis B virus, is the predominant cause of chronic viral hepatitis in children and adults. ${ }^{4}$ In industrialized countries, since the start of the hepatitis B virus vaccination program, $\mathrm{HCV}$ has become the most significant cause of chronic liver disease of infectious etiology in children. ${ }^{5}$ The overall worldwide prevalence of $\mathrm{HCV}$ varies geographically, but it is estimated at $3 \%$ with 150 million people with chronic infection. ${ }^{5}$ Data from the Centers for Disease Control and Prevention have shown that the seroprevalence of antibodies to $\mathrm{HCV}$ in the United States was $0.2 \%$ for children aged $6-11$ years and $0.4 \%$ for those aged $12-19$ years. ${ }^{6}$ Similar prevalence was found in western Europe, ${ }^{7}$ North America, ${ }^{8}$ Mongolia, ${ }^{9}$ and Japan, ${ }^{10}$ whereas a higher prevalence, up to $10 \%-15 \%$, was reported in Saudi Arabia and in parts of Africa. ${ }^{11,12}$ The seroprevalence of HCV infection in children is generally lower than in adults, ${ }^{5}$ and studies assessing the seroprevalence of $\mathrm{HCV}$ usually overestimate the prevalence of chronic hepatitis; however, a study undertaken to estimate the direct medical costs of care for chronic HCV-infected children showed that pediatric hepatitis $\mathrm{C}$ is an important health care issue, with associated costs in the United States estimated between US $\$ 17$ and $\$ 40$ million annually that means US \$168-\$404 million over a 10-year period..$^{13}$

Before 1992, the mode of acquisition of HCV infection in children was predominantly via transfusion of blood or blood products. ${ }^{14-16}$ Childhood cancer survivors, children with hematological disorders necessitating the use of repeated transfusion of blood products, and children with renal failure who were treated with hemodialysis all exhibited a high incidence of $\mathrm{HCV}$ infection. ${ }^{17,18}$ After the implementation of universal testing of blood products, transmission of virus from the mother to child became the leading source of HCV infection in children. ${ }^{14-16}$ Overall, the risk of perinatal transmission of HCV from HCV RNA-positive mothers ranges between $1 \%$ and $6 \%$ (mean 3\%-4\%). ${ }^{19}$ Many factors were examined in multiple studies in relation to the risk of perinatal transmission of HCV. Different risk factors often coexist in the same mothers. ${ }^{19}$ Perinatal transmission is confined almost always to women with detectable HCV RNA in the peripheral blood by the polymerase chain reaction (PCR), ${ }^{20}$ but all children born to women with anti-HCV antibodies should be tested for $\mathrm{HCV}^{21}$ Some studies reported that a high concentration of serum HCV RNA is associated with a higher risk of transmission, ${ }^{22-27}$ whereas others failed to demonstrate this association and found considerable overlapping in concentrations of HCV RNA between transmitting and nontransmitting mothers. ${ }^{20,28,29}$ Maternal peripheral blood mononuclear cell infection by $\mathrm{HCV}^{30,31}$ membrane rupture of longer than 6 hours before delivery, ${ }^{29,32,33}$ and procedures exposing the infant to maternal blood infected with $\mathrm{HCV}$ during vaginal delivery are associated with an increased risk of transmission. ${ }^{29,34}$ Maternal coinfection with $\mathrm{HCV}$ and human immunodeficiency virus ${ }^{35}$ and maternal history of intravenous drug use ${ }^{36}$ and HCV infection of the sexual partner of the mother ${ }^{37}$ predict the risk of perinatal transmission and are dependent on the peripheral blood mononuclear cell infection by HCV. ${ }^{19}$ Delivery by Cesarean section is not recommended in pregnant women infected with HCV. Infected mothers can safely breast-feed their infants if the nipples are not damaged. ${ }^{38-41} \mathrm{~A}$ previous delivery of a child infected perinatally with $\mathrm{HCV}$ does not increase the risk of transmission in subsequent pregnancies. ${ }^{42}$ Immunogenetic factors and $\mathrm{HCV}$ genotypes are not related to $\mathrm{HCV}$ perinatal transmission. ${ }^{20,43-45}$ Despite an increased understanding of the risk factors involved in perinatal transmission of $\mathrm{HCV}$, the ultimate mechanism and the exact timing of mother-to-child transmission of $\mathrm{HCV}$ infection are still unknown. ${ }^{19}$

\section{Hepatitis $C$ in children}

Following perinatal transmission, spontaneous HCV RNA clearance, with subsequent transaminases normalization, is a rare event occurring in about $20 \%$ of perinatally infected children in the first 5 years of life..$^{46,47}$ More than half of the patients who spontaneously clear the infection develop an alanine transaminase peak greater than five times the normal value at the onset of the infection and are infected by HCV genotype $3 .{ }^{47}$ In the patients who do not clear the virus, chronic HCV infection tends to persist into adult life. ${ }^{47,48}$ Most children with hepatitis $\mathrm{C}$ are, thus, expected to contribute to the pool of infected adult patients. The cumulative probability of chronic progression has been estimated in different studies to be around $80 \%{ }^{46,47}$ Children with chronic hepatitis $\mathrm{C}$ are often asymptomatic. ${ }^{46,47}$ Data from a large, multicenter, prospective study of children born to HCVinfected women in Europe showed that hepatomegaly was the only clinical sign reported in $10 \%$ of the cohort. ${ }^{46}$ The pattern of transaminases during chronic infection in children varies, but almost half of them have sustained cytolysis at follow-up visits. ${ }^{16,47,49,50}$ Although HCV-related end-stage liver disease is still the most frequent indication for liver transplantation in adult patients, cirrhosis and hepatocellular carcinoma are rarely seen in young babies or adolescents without underlying disorders. Severe outcomes of chronic hepatitis $\mathrm{C}$ have been reported for special groups of patients given multiple blood transfusions, such as children with bleeding disorders or thalassemia. ${ }^{51}$ In the largest pediatric observational study 
including both babies with perinatal infection and children with parenteral sources of contagion, most of whom remained untreated, persistent viral replication during chronic infection has been demonstrated to lead to end-stage liver disease in a small subgroup characterized by perinatal exposure, maternal drug use, and infection with HCV genotype $1 \mathrm{a} .{ }^{48}$ Different authors described small case series of cirrhosis in children, which seem to support the evidence that vertically infected children develop cirrhosis more frequently than transfused children with no underlying systemic disease. ${ }^{52-55}$ Overall, liver fibrosis seems to increase with the age of the patient and/ or with the duration of the disease, and older adolescents and young adults have more severe fibrosis than children. ${ }^{56,57}$

A particular aspect of the host-virus interaction in children with chronic hepatitis $\mathrm{C}$, which affects the progression of $\mathrm{HCV}$-related liver damage, is the production of liver-kidney microsomal antibodies. Liver-kidney microsomal antibodies are rarely seen in adults but are detectable in around $7 \%$ of the children with chronic infection. ${ }^{48}$ In children with positive liver-kidney microsomal antibodies, liver histology findings are significantly more severe. ${ }^{58}$ Similar to adults, ${ }^{59-61}$ recent data demonstrate that in children with chronic hepatitis $\mathrm{C}$, the presence of steatosis is associated with more severe fibrosis and a reduced response to interferon- $\alpha$ treatment. ${ }^{62}$ Furthermore, with regard to response to the treatment, a marked $\mathrm{HCV}$ quasi-species diversification has been described in children during chronic infection that could be important for virus persistence and might impair the response to antiviral therapy during childhood. ${ }^{63}$

In adults with chronic hepatitis $\mathrm{C}$, health-related quality of life is significantly poorer when compared with the normal population. ${ }^{64,65}$ The reduction in health-related quality of life is not related to the degree of liver inflammation and improves with therapy, particularly with successful viral eradication. ${ }^{66}$ Health-related quality of life is an important health outcome required to inform health-care decision-making for adult patients with chronic $\mathrm{HCV}$ infection. ${ }^{67} \mathrm{~A}$ recent study showed for the first time that both the physical and psychosocial health of asymptomatic children with chronic HCV infection are significantly reduced compared with children without HCV. Almost all domains of health were affected, the most significant reductions being in parental assessment of overall health of their child and the impact of the child's health in terms of parental distress and additional time required caring

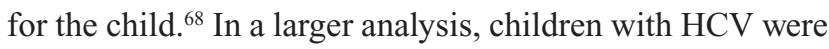
shown to have similar overall health-related quality of life but worse cognitive functioning than their noninfected peers. ${ }^{69}$ Moreover, in this study, caregivers were highly distressed about their children's medical circumstances compared with a normative sample. ${ }^{69}$

\section{Treatment for chronic hepatitis $C$ in children}

The experiences with therapy in children are based on the earlier and continuing data from adult trials. The currently recommended therapy for chronic HCV infection in adults is the combination of a peginterferon- $\alpha$ and ribavirin. ${ }^{70}$ The choice of this regimen was based upon the results of randomized clinical trials that demonstrated the superiority of this combination treatment over standard interferon- $\alpha$ and ribavirin. ${ }^{70}$ The addition of polyethylene glycol to interferon- $\alpha$ increases its half-life allowing onceweekly doses, reduces its volume of distribution, and leads to more sustained plasma levels resulting in more viral suppression. Few data are available on monotherapy with interferon- $\alpha$, on the combined use of interferon- $\alpha$ and ribavirin, and on monotherapy with peginterferon- $\alpha$ in children. ${ }^{71}$ Weekly dosing of peginterferon- $\alpha$ is more acceptable than thrice-weekly dosing of nonpegylated interferon- $\alpha$, especially in children who may be particularly sensitive to the regular need for subcutaneous injections. The use of the combined treatment, peginterferon- $\alpha-2 b$ with ribavirin, has been approved by the US Food and Drug Administration (in December 2008) and by the European Medicines Agency (in December 2009) for children older than 3 years and appears as the most effective and safe option among available treatments.

\section{Combined treatment with peginterferon- $\alpha$ and ribavirin}

Few studies are available on the combined treatment with subcutaneous peginterferon- $\alpha-2$ a or peginterferon- $\alpha-2 b$ and oral ribavirin in children with chronic hepatitis C. ${ }^{54,72-79}$ In this review, we examine the results of seven studies on the combined treatment. Only five trials have evaluated the efficacy of this combination therapy, of which four had been fully published ${ }^{72-75}$ and one, the PEDS-C trial, is available in abstract form. ${ }^{76}$ The PEDS-C trial is the only Phase III, interventional, double-blind, randomized, placebo-controlled, multicenter study designed to compare the efficacy and the safety of peginterferon- $\alpha-2$ a alone with its combination with ribavirin as a treatment of chronic $\mathrm{HCV}$ infection in children and adolescents. A formal paper has not been published yet, but the main results of the study have been presented at the 59th Annual Meeting of the American Association for the Study of Liver Diseases. ${ }^{76}$ Two further studies described 
small cohorts of children with chronic hepatitis $\mathrm{C}$ treated with peginterferon- $\alpha-2 b$ and ribavirin. ${ }^{77,78}$ The first, published by Baker et al, is a retrospective/prospective study reporting observations on 10 adolescents. The second is a retrospective, multicenter, collaborative study by the Japan Society of Pediatric Hepatology on 33 children and young adults. ${ }^{78}$ Two more studies on combined treatment have been published, but were excluded from the analysis performed in this review, in one case because it was not possible to extrapolate the children treated with peginterferon- $\alpha-2 \mathrm{a}$ and those treated with peginterferon- $\alpha-2 b^{79}$ and the other because the patients enrolled were on treatment at the end of the follow-up. ${ }^{54}$

\section{Inclusion and exclusion criteria}

In all the above-mentioned trials, inclusion and exclusion criteria were defined clearly. ${ }^{72-76}$ In the PEDS-C abstract ${ }^{76}$ and in the article by Wirth et al, ${ }^{74}$ the inclusion and exclusion criteria are not fully reported, but the complete lists of the criteria are available to access at ClinicalTrials.gov, the registry of federally and privately supported clinical trials conducted in the United States and around the world, under the identifiers NCT00100659 and NCT00104052, respectively.

The first inclusion criteria for all the studies was the presence of chronic hepatitis $\mathrm{C}$ with detectable serum $\mathrm{HCV}$ $\mathrm{RNA}^{72-78}$ independent of HCV genotype and the mode of infection. ${ }^{72-78}$ In the study by Wirth et $\mathrm{al}^{74}$ published in 2010 , in the PEDS-C trial, ${ }^{76}$ and in the study by Baker et $\mathrm{al}^{77}$ patients were enrolled only if HCV RNA was detected for more than 6 months before treatment. In the study by Jara et $\mathrm{al}^{73}$ strict chronic infection inclusion criteria were defined, and $\mathrm{HCV}$ RNA was required to be detectable for a minimum of 3 years to exclude spontaneous resolution of $\mathrm{HCV}$ infection that rarely occurs in children longer than 3 years after exposure to HCV. For the same reason, in the same study, all the patients had continuous or intermittently elevated transaminases for a minimum of 3 years. ${ }^{73}$ In the study by Wirth et a ${ }^{74}$ published in 2010, patients were excluded if the serum alanine transaminase level was more than 10 times the upper limit of normal within the 6 months before the beginning of the treatment. In the remaining studies, the enrollment was independent of the levels of serum transaminases. ${ }^{72,76-78}$

The pretreatment liver biopsy was not mandatory in the three trials. ${ }^{72,73,75}$ In the study by Wirth et $\mathrm{al}^{74}$ published in 2010, a pretreatment liver biopsy with evidence of fibrosis, inflammatory activity, or both was an inclusion criteria for all the patients with the exception of children aged 3-11 years with elevated alanine transaminase within 1 year before enrollment. In the PEDS-C trial, a liver biopsy, obtained within 24 months from the start of the treatment and showing chronic liver disease as indicated by inflammation and/or fibrosis not consistent with other known liver diseases and not normal, was required. ${ }^{76}$ The liver biopsies were available from all the 10 patients enrolled in the study by Baker et al. ${ }^{77}$

Exclusion criteria across different studies included neutropenia, ${ }^{72-74,76-78}$ thrombocytopenia, ${ }^{72-74,76-78}$ anemia, ${ }^{72-78}$ human immunodeficiency virus coinfection, ${ }^{72-78}$ hepatitis $\mathrm{B}$ virus coinfection, ${ }^{72-78}$ decompensated liver disease and cirrhosis, ${ }^{72-78}$ psychiatric and neurologic diseases, ${ }^{72-78}$ renal insufficiency, ${ }^{72-76}$ alcohol or drug dependence, ${ }^{74-76}$ retinopathy, ${ }^{74-76}$ and other coexisting medical conditions. ${ }^{72-78}$ In the study by Baker et $\mathrm{al}^{77}$ three patients had hemophilia, one had von Willebrand disease, and one had Hirschsprung disease. Three studies excluded patients previously treated for $\mathrm{HCV}$ infection. ${ }^{74-76}$ In the study by Wirth et $\mathrm{al}^{72}$ published in 2005 , they enrolled patients irrespective of previous treatment, but only five of the patients enrolled had received interferon- $\alpha$ monotherapy. In the study by Jara et $\mathrm{al}^{73}$ nonresponders to interferon- $\alpha$ monotherapy were eligible for enrollment but could not account for more than $25 \%$ of the patients' population. A negative pregnancy test was required in most studies for females with reproductive potential before the start of medication. ${ }^{72-74,76,78}$ With regard to the presence of nonorganspecific autoantibodies and autoimmune liver disease, in the study by Wirth et $\mathrm{al}^{72}$ published in 2005 and in the retrospective analysis by the Japan Society of Pediatric Hepatology, ${ }^{78}$ patients were excluded if positive before treatment for liverkidney microsomal antibodies or for antinuclear and antismooth muscle antibodies, respectively. In the PEDS-C trial, patients were excluded if antinuclear antibodies were $\geq 1: 160$, antismooth muscle antibodies $\geq 1: 180$, and anti-liver-kidney microsomal antibodies $\geq 60 \mathrm{U.}^{76}$ In the study by Jara et al ${ }^{73}$ patients testing positive for antinuclear antibodies, smooth muscle antibodies, and liver-kidney microsomal antibodies were enrolled if other features did not suggest autoimmune hepatitis. In the study by Wirth et $\mathrm{al}^{74}$ published in 2010 , patients were excluded if antinuclear antibodies were $>1: 160$. In two studies, ${ }^{72,78}$ all the patients were defined "thyroid normal" before treatment. Jara et $\mathrm{al}^{73}$ reported two patients with small elevations either in thyroid-stimulating hormone (TSH) level or in thyroxin level at baseline. In the study published by Wirth et $\mathrm{al}^{74}$ in 2010 and in the PEDS-C trial, ${ }^{76}$ patients were enrolled if they had normal TSH, absence of antithyroid antibodies, and no history of poorly controlled thyroid disease. In the same study, no patients should have received any systemic antiviral therapy in the 6 weeks before the first dose of study drug, with the exception of those who had taken or 
were expected to require acyclovir for herpetic lesions. ${ }^{76}$ Also, in the study by Baker et al ${ }^{77}$ patients were excluded from the treatment if they had received any antiviral treatment other than interferon.

\section{Type of treatment and doses}

As shown in Table 1, combination therapy with peginterferon$\alpha-2 \mathrm{a}$ and ribavirin was used in two of the seven studies. ${ }^{75,76}$ All the other studies evaluated combination therapy with peginterferon- $\alpha-2 b$ and ribavirin. ${ }^{72-74,77,78}$ The dose of subcutaneous peginterferon- $\alpha-2 b$ administered to patients in the trials and in the retrospective studies was $1.5 \mu \mathrm{g} / \mathrm{kg}$ once weekly, whereas for peginterferon- $\alpha-2$ a was $100 \mu \mathrm{g} / \mathrm{m}^{2}$. Only in the study by Jara et $\mathrm{al}^{73}$ the dose of peginterferon- $\alpha-2 b$ was $1 \mu \mathrm{g} / \mathrm{kg}$ once weekly. Ribavirin was administered orally at the dosage of $15 \mathrm{mg} / \mathrm{kg} / \mathrm{d}$ in two divided doses.

\section{Duration of treatment}

The duration of the treatment is relatively variable among the different studies. Table 1 summarizes the protocols used. In most studies, patients infected with HCV genotypes 1 and 4 were planned to receive treatment for 48 weeks and were withdrawn from treatment if qualitative $\mathrm{HCV}$ PCR was positive at treatment week 24. Wirth et $\mathrm{al}^{74}$ in 2010 discontinued the treatment also in patients with $<2 \log _{10}$ drop in HCV RNA at treatment week 12 . In the study by Jara et $\mathrm{al}^{73}$ patients with genotypes 1 or 4 who tolerated well the treatment were not advised to stop it if HCV RNA was positive after 24 weeks of treatment. In the retrospective study by Tajiri et al $^{78}$ some patients with genotype 1 were treated for 72 weeks. Children with HCV genotypes 2 and 3 were treated usually for 24 weeks, but in some studies, the treatment was prolonged up to 48 weeks. $^{72,74,76,78}$

\section{Response to treatment: definitions}

Multiple definitions of the response to treatment are possible according to the detection or nondetection of plasma HCV RNA as measured by quantitative real-time PCR at different time intervals from the beginning or from the end of the treatment. To make possible the comparison among the different results, certain definitions need to be clarified. Table 2 summarizes the most commonly accepted definitions of the responses to treatment. Some authors instead of the detection have used the variations in the HCV RNA levels to characterize the response to treatment. Wirth et $\mathrm{al}^{74}$ in 2010 , eg, used a $<2 \log _{10}$ drop in HCV RNA at treatment week 12

Table I Type of treatment, doses, duration, and schedules of clinical evaluations and laboratory tests for the assessment of safety and efficacy in the different studies

\begin{tabular}{|c|c|c|c|}
\hline Study & Type of treatment and doses & Duration & $\begin{array}{l}\text { Clinical evaluations and laboratory tests } \\
\text { for the assessment of safety and efficacy }\end{array}$ \\
\hline Wirth et $\mathrm{al}^{72}$ & $\begin{array}{l}\text { PEG-IFN- } \alpha-2 b \quad 1.5 \mu g / k g / w k \\
\text { Ribavirin } 15 \mathrm{mg} / \mathrm{kg} / \mathrm{d}\end{array}$ & $\begin{array}{l}\text { GI: } 48 \text { wk } \\
\text { G2, G3: } 8 \text { patients for } 48 \text { wk, } \\
5 \text { patients for } 24 \text { wk }\end{array}$ & $\begin{array}{l}\text { Treatment weeks: } 2,4,8 \text {, and then } \\
\text { every } 12 \text { wk until the EOT. } \\
\text { FU: wk } 12 \text { and } 24 \text { after the EOT }\end{array}$ \\
\hline Jara et $\mathrm{al}^{73}$ & $\begin{array}{l}\text { PEG-IFN- } \alpha-2 b \text { I } \mu g / \mathrm{kg} / \mathrm{wk} \\
\text { Ribavirin } 15 \mathrm{mg} / \mathrm{kg} / \mathrm{d}\end{array}$ & $\begin{array}{l}\text { GI: } 48 \text { wk } \\
\text { G2, G3: } 24 \text { wk }\end{array}$ & $\begin{array}{l}\text { Treatment weeks: I, } 2,3,4,8,16,20,24 \text {, } \\
\text { and then } 4 \text {-wk to I2-wk } \\
\text { intervals until the EOT } \\
\text { FU: wk I } 2 \text { and } 24 \text { after the EOT }\end{array}$ \\
\hline Wirth et $\mathrm{al}^{74}$ & $\begin{array}{l}\text { PEG-IFN- } \alpha-2 \mathrm{~b} 60 \mu \mathrm{g} / \mathrm{m}^{2} / \mathrm{wk} \\
(\mathrm{I} .5 \mu \mathrm{g} / \mathrm{kg} / \mathrm{wk}) \\
\text { Ribavirin } 15 \mathrm{mg} / \mathrm{kg} / \mathrm{d} \\
(\max 1,200 \mathrm{mg}=90 \mathrm{~kg})\end{array}$ & $\begin{array}{l}\text { GI, G4: } 48 \text { wk } \\
\text { G3 with load > 600,000 IU/mL:a } 48 \text { wk } \\
\text { G3 with load > 600,000IU/mL: } 24 \text { wk } \\
\text { G2: } 24 \text { wk }\end{array}$ & $\begin{array}{l}\text { Treatment weeks: } 2,4,12,24,30,48 \\
\text { FU: wk 4, I2, and } 24 \text { after the EOT }\end{array}$ \\
\hline Sokal et a $7^{75}$ & $\begin{array}{l}\text { PEG-IFN- } \alpha-2 \text { a } 100 \mu g / \mathrm{m}^{2} / \mathrm{wk} \\
\text { Ribavirin } 15 \mathrm{mg} / \mathrm{kg} / \mathrm{d} \\
(\max 1,200 \mathrm{mg})\end{array}$ & $\begin{array}{l}\text { GI, G4, G5, G6: } 48 \text { wk } \\
\text { G2, G3: } 24 \text { wk }\end{array}$ & $\begin{array}{l}\text { Treatment weeks: } 2,6,12,24,36,48 \\
\text { FU: wk } 12 \text { and } 24 \text { after the EOT }\end{array}$ \\
\hline Schwarz et $\mathrm{al}^{76}$ & $\begin{array}{l}\text { PEG-IFN- } \alpha-2 a \text { I } 80 \mu g / 1.73 \text { m²/wk } \\
\text { Ribavirin } 15 \mathrm{mg} / \mathrm{kg} / \mathrm{d}(\max 1,200 \mathrm{mg})\end{array}$ & All genotypes: $48 \mathrm{wk}$ & - \\
\hline Baker et $\mathrm{a}^{17}$ & $\begin{array}{l}\text { PEG-IFN } \alpha-2 b \quad 1.5 \mu \mathrm{g} / \mathrm{kg} / \mathrm{wk} \\
\text { Ribavirin } 800 \mathrm{mg} / \mathrm{d}\end{array}$ & $\begin{array}{l}\text { GI: } 48 \text { wk } \\
\text { G3: } 24 \text { wk }\end{array}$ & $\begin{array}{l}\text { Treatment weeks: } 2,4,24,48 \\
\text { FU: weeks } 24 \text { after the EOT }\end{array}$ \\
\hline Tajiri et al ${ }^{78}$ & $\begin{array}{l}\text { PEG-IFN- } \alpha-2 b \text { I. } 5 \mu g / \mathrm{kg} / \mathrm{wk} \\
\text { Ribavirin I } 5 \mathrm{mg} / \mathrm{kg} / \mathrm{d}<40 \mathrm{~kg} \text {; } \\
600 \mathrm{mg} / \mathrm{d} 40-60 \mathrm{~kg} ; 800 \mathrm{mg} / \mathrm{d} \\
60-80 \mathrm{~kg} ; \mathrm{I} \mathrm{g} / \mathrm{d}>80 \mathrm{~kg}\end{array}$ & $\begin{array}{l}\text { GI: } 48 \text { wk, } 72 \text { wk for } 4 \text { patients } \\
\text { G2: } 24 \text { or } 48 \text { wk (no. not provided) }\end{array}$ & $\begin{array}{l}\text { Treatment weeks: } 2,4,6,8 \text {, and then } \\
\text { every } 4 \text { wk until the EOT } \\
\text { FU: wk } 12 \text { and } 24 \text { after the EOT }\end{array}$ \\
\hline
\end{tabular}

Note: aEight of nine patients infected with G3 with load $>600,000 \mathrm{IU} / \mathrm{mL}$ were treated for 24 wk instead of the protocol-defined $48 \mathrm{wk}$.

Abbreviations: PEG-IFN, peginterferon; EOT, end of treatment; FU, follow-up; G, genotype; wk, week. 
Table 2 Definitions of the response to treatment according to HCV RNA detection as measured by quantitative real-time polymerase chain reaction and to the time interval from the beginning or from the end of the treatment

Rapid virological response: undetectable plasma HCV RNA at treatment week 4

Early virological response: undetectable plasma HCV RNA at treatment week 12

Sustained virological response: undetectable plasma HCV RNA 24 wk after the end of treatment

End of treatment response: undetectable plasma HCV RNA at the end of treatment

Relapse: undetectable plasma HCV RNA at last treatment visit, detectable HCV RNA at the last follow-up visit

Nonresponder: detectable HCV RNA at treatment week 24

Breakthrough: reappearance of HCV RNA in serum while still

on treatment

Abbreviation: $\mathrm{HCV}$, hepatitis $\mathrm{C}$ virus.

as an additional criteria to define a nonresponder patient. In the study by Sokal et al ${ }^{75}$ early virological response (EVR) was defined as an at least a $2 \log _{10}$ drop in HCV RNA levels at week 12 compared with baseline. As a consequence, different definitions are available in different studies. Unless otherwise specified, in this review, the response to treatment is described according to the definitions of Table 2.

\section{Assessment of safety and efficacy}

Clinical evaluations and laboratory tests for the assessment of safety and efficacy were performed in the different studies following different schedules (Table 1). According to the previous definitions (Table 2), for the complete assessment of efficacy, important HCV RNA determinations are those planned at treatment week 4 (rapid virological response [RVR]), 12 (EVR), 24 (end of treatment response [ETR] for some patients), 36, 48 (ETR for some patients), and every 12 weeks for another 24 weeks after the end of the treatment (sustained virological response [SVR]). Clinical and laboratory evaluations were usually more frequent in the first months of the treatment in order to detect adverse events. A reasonable approach suggests clinical and laboratory evaluations every 2 weeks in the first phase of therapy, monthly up to 6 months, every 3 months for the remaining period of treatment, and for another 6 months after the end of the treatment. ${ }^{80}$

Different approaches have been used in different studies with regard to pregnancy test and adequate contraception. These points are important in sexually active females of child-bearing potential. Pregnancy tests before the start of medication were performed only in some studies. ${ }^{72-74,76,78}$ During antiviral therapy and for 6 months after the end of treatment, adolescents were instructed to use birth control ${ }^{73,78}$ or adequate contraception was compulsory. ${ }^{75,76}$ Exclusion of pregnancy during treatment was done by routine pregnancy testing, ${ }^{73,77}$ by parent's and patient's report at each visit, ${ }^{72}$ or when a possibility of pregnancy was present. ${ }^{78}$

In the PEDS-C trial, ophthalmologic examinations including slit lamp at enrollment and after 24 and 48 weeks of treatment were performed. ${ }^{76}$

\section{End points of the studies}

The primary end point in all the studies was the SVR rate. ${ }^{72-78}$ Biochemical response (defined as the normalization of serum alanine transaminase levels) was an end point only in some studies. ${ }^{72-74}$

\section{Sustained virological response}

SVR rates in the seven studies are summarized in Table 3 and range from $33 \%$ to $81 \%{ }^{72-78}$ When only the results of the trials were analyzed, the range is, irrespective of the genotype, $50 \%-68 \% .^{72-76}$ It is important to note that the overall SVR is not a representative result of a trial and does not allow the comparison of the results of different trials because distribution of genotypes and of the other determinants of SVR are different across the trials.

\section{Significant predictors of SVR}

The roles of different factors as predictors of SVR are reported in Table 4 . The viral genotype, ${ }^{72,74,75}$ the viremia levels among patients with genotype 1 infection, ${ }^{74}$ and the HCV RNA status at treatment week 4 (RVR) $)^{74,78}$ and 12th (EVR) ${ }^{73,74}$ have been demonstrated to be predictive of SVR in children who received combined treatment. As expected, based on adult's studies, the rates of virological response were significantly higher in patients infected with HCV genotypes 2 or 3 than in patients infected with other genotypes. ${ }^{72,74,75}$ In the PEDS-C study, SVRs for genotype 1 and genotype non- 1 were $47 \%$ and $80 \%$, respectively. ${ }^{76}$ In a recent study enrolling 12 adolescents infected with HCV genotype 4 treated with peginterferon- $\alpha-2 b$ and ribavirin, the SVR was observed in $75 \%$ of the patients treated. ${ }^{81}$ With regard to the mode of acquisition of HCV infection, in the study by Jara et $\mathrm{al}^{73}$ treatment was particularly effective in patients with parenterally acquired infection. However, statistical significance was not reached, probably due to the small number of enrolled patients. ${ }^{73} \mathrm{~A}$ similar tendency was demonstrated by Wirth et $\mathrm{al}^{72}$ and by Tajiri et al. ${ }^{78}$

In the study by Wirth et al, ${ }^{74}$ among patients with $\mathrm{HCV}$ genotype 1 infection, SVR was significantly higher in those with baseline viral loads $<600,000 \mathrm{IU} / \mathrm{mL}$ than in those 


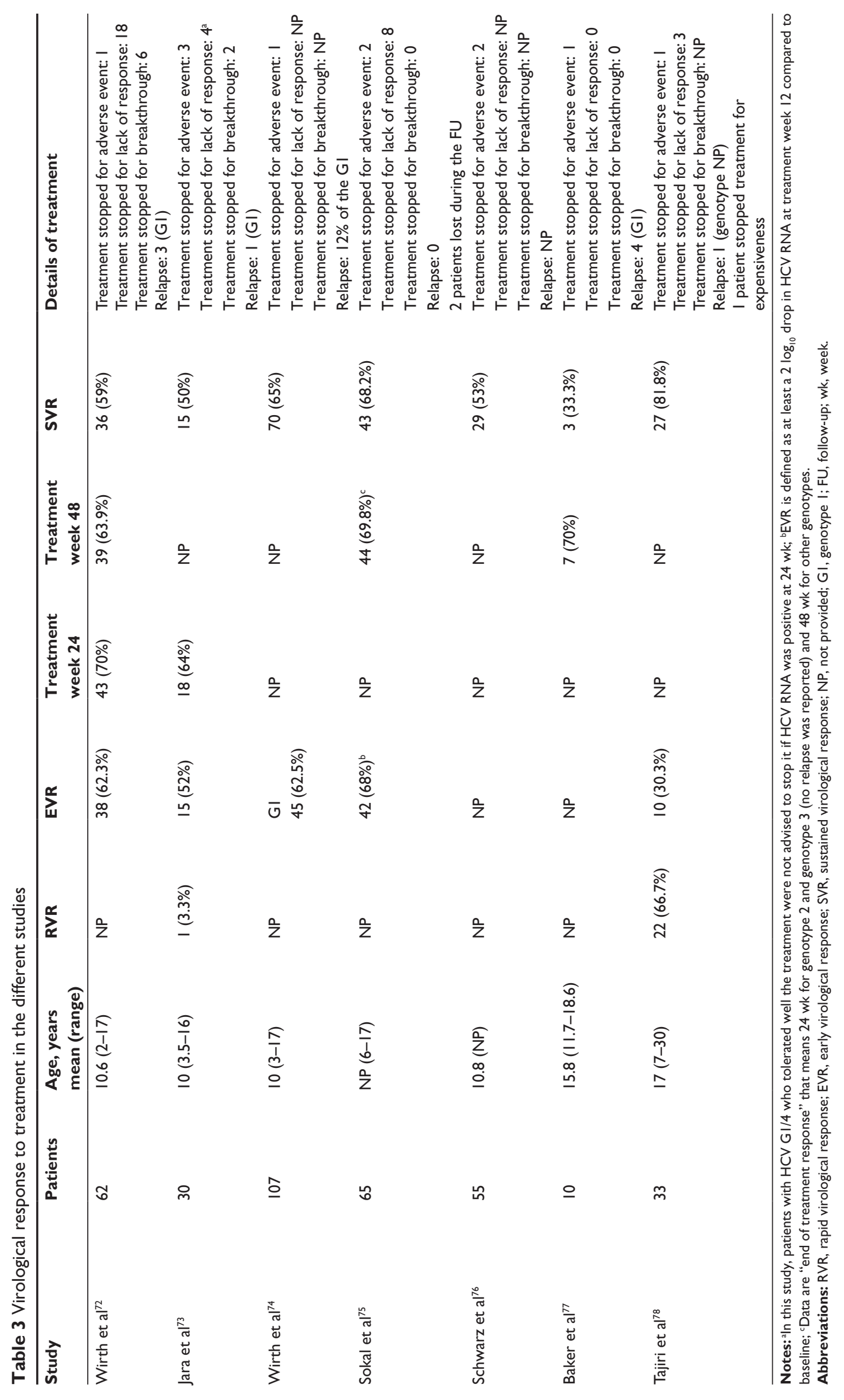




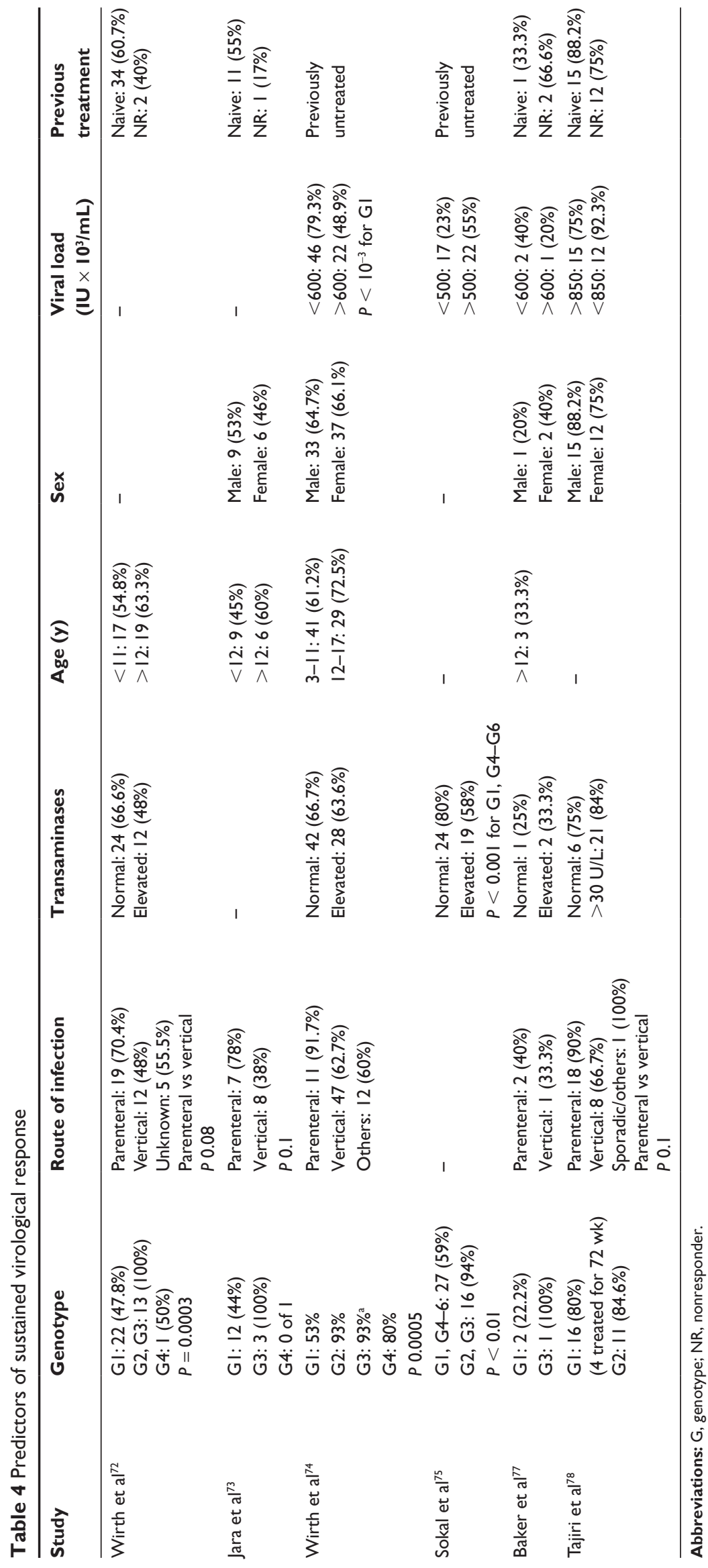


with baseline viral loads $>600,000 \mathrm{IU} / \mathrm{mL}$ ( $72 \%$ vs $29 \%$, $P=0.0006)$. In the study by Jara et $\mathrm{al}^{73} \mathrm{EVR}$ defined as HCV RNA-negative status at week 12 th and $>2 \log _{10}$ decrease in viral load at week 12 th was predictive of a SVR. In the study by Wirth et $\mathrm{al}^{74}$ published in 2010 , RVR and EVR were strong predictors of SVR. Overall, $89 \%$ of patients infected with HCV genotype 1 and with RVR and $84 \%$ of those with EVR attained SVR. ${ }^{74}$ In the study by Tajiri et al $^{78}$ RVR was significantly associated with SVR (odds ratio $=19.85 ; 95 \%$ confidence interval, 1.43-275.2; $P=0.02$ ). Among adult patients, the younger age has been associated with better response rates, whereas in the pediatric studies, age does not seem to influence response. ${ }^{72-78}$ In the studies by Wirth et $\mathrm{al}^{72,74}$ and in the study by Jara et al, ${ }^{73}$ adolescents seemed to have better response, but the results did not reach statistical significance. No significant relationship was found between transaminases' levels, sex, previous treatment, and the outcome of combined treatment. ${ }^{72-78}$ Few data are available on the effect of continuing treatment on nonresponders. In the study by Jara et $\mathrm{al}^{73} 6$ children with genotypes 1 and 4 continued therapy for 48 weeks even if HCV RNA was positive at treatment week 24; at the end of the treatment, all children remained HCV RNA positive. The only study reporting the influence of histological examination of the liver on the response to treatment was the Spanish study from Jara et $\mathrm{al}^{73}$ that did not show any relationship between the Knodell index and the SVR. Overall, in the different studies, inflammatory activity and fibrosis on histological examination were homogeneously low; therefore, the correlation between histological appearance and response to treatment cannot be expected.

Virological surveillance while on therapy is important to determine the predictors of response and predictors of nonresponse. It would be important to identify early nonresponders to apply stopping rules. In the study by Jara et $\mathrm{al}^{73}$ no cases with $<2 \log _{10}$ reduction at week 12 (ie, without EVR) achieved SVR. In the study by Wirth et $\mathrm{al}^{74}$ published in 2010, of the 20 patients who did not have an EVR, 14 did not achieve SVR while 6 did.

Children with HCV genotypes 2 and 3 were treated usually for 24 weeks, but in different studies, the treatment was prolonged up to 48 weeks. ${ }^{72,74,76,78}$ In the study by Wirth et al, ${ }^{72}$ eight patients infected with HCV genotypes 2 and 3 were treated for 48 weeks. All of them showed EVR, so it was not possible to obtain any information on the efficacy of prolonging the treatment for 48 weeks in terms of SVR. In the study by Wirth et al, ${ }^{74}$ patients with genotype 3 infection and baseline viral loads $\geq 600,000 \mathrm{IU} / \mathrm{mL}$ were planned to be treated for 48 weeks, but all attained SVR including 8 of 9 who were treated for 24 weeks. No information is available on the only patient who was treated for 48 weeks, particularly if he or she had or had not achieved EVR. No data are available on the issue of the efficacy of treatment of patients with HCV genotype 2 infection for 48 weeks instead of 24 weeks from the two remaining studies who adopted the same protocol. $^{76,78}$

The reappearance of HCV RNA in serum while still on treatment (ie, breakthrough) was a common event (Table 3 ). Interestingly, among the different studies, all the patients who relapsed were infected by $\mathrm{HCV}$ genotype 1 .

\section{Adverse events}

Table 5 summarizes the most common adverse events reported in the studies on combination therapy with peginterferon- $\alpha-2 \mathrm{a}$ and ribavirin, and Table 6 reports the causes of dose reduction and treatment discontinuation. ${ }^{72-78}$ Almost all the children enrolled experienced at least one mild adverse event. ${ }^{72-74,78}$ Flu-like symptoms including fever, decreased appetite, asthenia, and fatigue were observed usually during the first weeks of treatment, and in most patients resolved or became milder during the second 6 months. ${ }^{72-75,77,78}$ Only one patient reported by Wirth et $\mathrm{al}^{72}$ in 2005 developed diabetes mellitus that persisted even after the end of the treatment. In this patient, therapy was continued without changing dosage and SVR was achieved. ${ }^{72}$ The development of nonautoimmune thyroid disease is possible in untreated children with chronic $\mathrm{HCV}$ infection. ${ }^{82}$ Among the available series on combined treatment, only one study reported the results of thyroid assessment before the beginning of the treatment, ${ }^{73}$ whereas others enclosed thyroid function abnormality among the exclusion criteria. ${ }^{72,74,76,78}$ During treatment, in the different studies, the emergence of antithyroid antibodies, of elevation of TSH, and of hypothyroidism requiring substitutive therapy was significant (Table 5). ${ }^{72-75,78}$ The highest incidence of thyroid dysfunction was reported by Wirth et $\mathrm{al}^{74}$ in 2010 . In this study, $23 \%$ of the patients had at least 1 abnormal TSH value during the treatment or follow-up phases and $3 \%$ had clinical hypothyroidism. ${ }^{74}$ Five girls received levothyroxine, three for clinical hypothyroidism and two for elevated TSH. Three of these five patients were still receiving the medication at the end of the 24 -week follow-up period. ${ }^{74}$ Across the different studies, thyroid function abnormalities, TSH abnormalities, and antithyroid antibodies disappeared in most of the patients after the end of treatment, and levothyroxine was discontinued. ${ }^{72,78}$ Jara et $\mathrm{al}^{73}$ reported two patients who developed antithyroid antibodies during the treatment, and the 


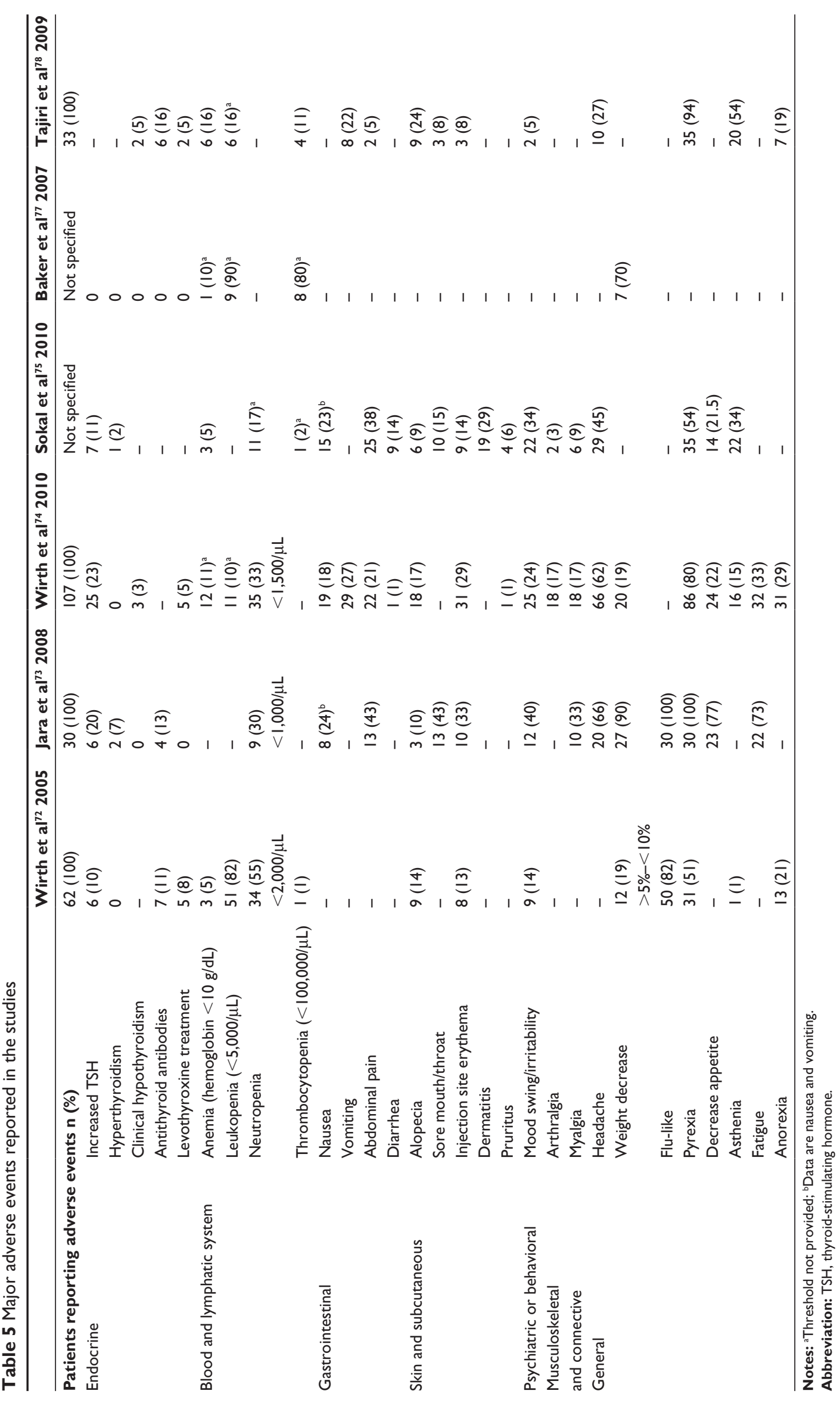


Table 6 Causes of dose reduction and treatment discontinuation

\begin{tabular}{|c|c|c|}
\hline & Dose reduction & Treatment discontinued for adverse events \\
\hline \multirow[t]{3}{*}{ Wirth et $\mathrm{al}^{72}$} & $4(6 \%)$ & I local reaction at injection site (week 10$)$ \\
\hline & 3 for neutropenia $(<\mathrm{I}, 700 / \mu \mathrm{L})$ & \\
\hline & I for weakness & \\
\hline \multirow[t]{2}{*}{ Jara et $\mathrm{al}^{73}$} & 7 (23\%) for neutropenia $(<I, 000 / \mu \mathrm{L})$ & I high-grade fever, hallucinations (week I), \\
\hline & & 2 hyperthyroidism (weeks 16 and 36 ) \\
\hline \multirow[t]{5}{*}{ Wirth et $\mathrm{al}^{74}$} & $27(25 \%)$ & I thrombocytopenia (week 42) \\
\hline & 13 for neutropenia $(<750 / \mu \mathrm{L})$ & \\
\hline & II for weight loss & \\
\hline & 7 for anemia $(<10 \mathrm{~g} / \mathrm{dL})$ & \\
\hline & I for pruritus, I for vomiting, I for diarrhea & \\
\hline \multirow[t]{4}{*}{ Sokal et $\mathrm{a}^{75}$} & $18(28 \%)$ & I acute hepatitis \\
\hline & II for neutropenia (threshold not provided) & I laboratory abnormality/thyrotoxicosis \\
\hline & 3 for anemia $(<10 \mathrm{~g} / \mathrm{dL})$ & \\
\hline & I for thrombocytopenia, I for weakness, I for laboratory abnormalities & \\
\hline \multirow[t]{3}{*}{ Baker et a $\mathbf{l}^{77}$} & $5(50 \%)$ & I not specified \\
\hline & 4 for weight loss & \\
\hline & I for anemia $(<10 \mathrm{~g} / \mathrm{dL})$ & \\
\hline \multirow[t]{4}{*}{ Tajiri et $\mathrm{al}^{78}$} & $21(63 \%)$ & I severe degree anemia, leucopenia, and lethargy \\
\hline & 6 for neutropenia $(1,400-1,800 / \mu \mathrm{L})$ & \\
\hline & II for anemia (undefined) & \\
\hline & 4 for weakness & \\
\hline
\end{tabular}

condition persisted off-therapy. Furthermore, hyperthyroidism $^{73}$ and thyrotoxicosis ${ }^{75}$ have been reported as reasons for discontinuing the treatment in three patients (Table 6).

Anemia, leukopenia, and neutropenia were common side effects and common causes of treatment discontinuation or dose reduction (Tables 5 and 6). ${ }^{72-75,77,78}$ It is difficult to compare the prevalence of these side effects in the different studies. The lower values under which dose reduction or discontinuation were required were always defined, but the criteria for diagnosing and reporting anemia, leukopenia, and neutropenia as side effects were often not provided. ${ }^{72-75,77,78}$ It can be speculated that even if it has not been specified, the lower value of the normal range for age and sex was used. Generally, the mean hemoglobin levels were described to decrease during the first 6 weeks of treatment. Subsequently, hemoglobin levels stabilized but remained below the normal range during the treatment and rose to former values at the end of the follow-up. Only the study by Baker et $\mathrm{al}^{77}$ stated that bone marrow stimulants were not used in any of the patients to prevent or treat anemia. The patients enrolled in the study by Jara et $\mathrm{al}^{73}$ received oral vitamin E supplements during treatment to alleviate ribavirin-induced hemolytic anemia. Across the different studies, leukocytes and neutrophils' counts tended to decrease during the first 2 weeks of treatment and in the majority of patients were below the normal value at week 6th of treatment. Subsequently, the counts stabilized but remained below the normal range for the remainder of the treatment period, increasing rapidly to baseline values after the completion of treatment. The median platelet count decreased progressively below the normal values during the first 12 weeks of treatment. After the treatment was completed, the median platelet counts returned to normal values at 12 weeks of follow-up.

Nausea, vomiting, and abdominal pain are the most common gastrointestinal symptoms reported. Transient behavioral changes have been described in 5\%-40\% of the patients enrolled in the available series, $;^{72-75,77,78}$ Sokal et $\mathrm{al}^{75}$ reported an $18 \%$ prevalence of insomnia.

With regard to the development of nonorgan-specific autoantibodies, only the study by Jara et $\mathrm{al}^{73}$ provided detailed information. Seven patients became antinuclear antibodies positive during treatment; ${ }^{73}$ high antinuclear antibodies' titer (1:640) was detected in one patient. Antinuclear antibodies positivity persisted at low titers in the five patients who had this marker at baseline. No patient developed liver-kidney microsomal antibodies during the study. Patients with detectable liver-kidney microsomal antibodies at baseline showed either stable or varying titers. No specific liver function events occurred in antinuclear antibodies-positive or liverkidney microsomal antibodies-positive patients during or after therapy.

One of the major issues of the treatment with interferon in children is the growth. Many patients had significant weight loss during the treatment. In the study by Wirth et al, ${ }^{72}$ no patient lost more than $10 \%$ of his or her weight before therapy. The mean decrease in body weight was $4.8 \%$ by 
week 24 in the study by Jara et $\mathrm{al}^{73}$ but returned to baseline values by week 48 . Compensatory weight gain after the discontinuation of the treatment was described in most patients by Wirth et al. ${ }^{74}$ On one side, a nonsignificant weight decrease was observed at the end of treatment by Sokal et al. ${ }^{75}$ On the other side, weight gain was described in 5\% of the patients enrolled in the study by Wirth et $\mathrm{al}^{72}$ and in two patients reported by Baker et al. ${ }^{77}$ With regard to height, in the study by Jara et $\mathrm{al}^{73}$ growth during the 48-week treatment period was reduced in 22 of 26 cases by $1.6 \mathrm{~cm}$ compared with the growth velocity 50th percentile for age and sex. Growth velocity was entirely normal in the 6-month period after the end of treatment; however, the modest decrease in height percentile observed during therapy was not recovered. ${ }^{73}$ Wirth et $\mathrm{l}^{74}$ described a clearly inhibited growth (ie, growth velocity below the 3 rd percentile) in $70 \%$ of the patients during the treatment phase. During the follow-up period, most patients demonstrated faster than normal growth or improved growth velocity, which was approximately two-fold greater during the follow-up period than during the treatment period. ${ }^{74}$ Decrease in mean height percentile during treatment seemed to be related to the duration of the treatment in patients whose treatment duration was longer than in those whose treatment duration was shorter. ${ }^{74}$ No significant effect on height growth was observed in the study by Sokal et al ${ }^{75}$ where the follow-up height values were comparable to the pretreatment height values. The long-term effects of treatment on children's growth are currently under investigation in some of the patients treated in the study published by Wirth et $\mathrm{al}^{74}$ who are currently enrolled in a 5-year follow-up study.

A recent study has been published on ophthalmologic complications as a satellite of the PEDS-C trial describing ischemic retinopathy, uveitis, and transient monocular blindness in 3 of 114 patients $(2.6 \%){ }^{83}$

\section{Conclusion}

$\mathrm{HCV}$ is the most common cause of chronic liver disease of infectious etiology in children. Most of the children infected with HCV are asymptomatic, and only a few of them develop signs and symptoms of end-stage liver disease early in life. It is not possible to predict in which patient $\mathrm{HCV}$ infection will have a bad outcome or the critical time in early adulthood when the disease progression will accelerate.

Peginterferon- $\alpha$ plus ribavirin treatment has been established as standard therapy in adults with chronic HCV infection. Data on the efficacy of combined treatment with peginterferon- $\alpha$ and ribavirin in children are encouraging and support the wider use of the treatment in children with chronic infection. The combination therapy is highly effective in children infected with HCV genotypes 2 and 3 (SVR $>90 \%)$. Around $50 \%$ of the children infected with HCV genotype 1 will achieve SVR with this treatment. The combined treatment generally is tolerated well, but the safety is still a concern. The limited data, so far available, on the use of peginterferon- $\alpha$ and ribavirin in children demonstrate that adverse events are common but only a few patients experienced severe adverse events during the treatment.

It is important that in the future, children with chronic $\mathrm{HCV}$ infection be treated in the contest of clinical trials in specialized centers with close monitoring of side effects. Further studies with larger number of patients will be helpful in elucidating predictors of response and possible modifications of the current treatment schedule that could improve the efficacy.

\section{Disclosure}

The authors report no conflicts of interest in this work.

\section{References}

1. Choo QL, Kuo G, Weiner AJ, et al. Isolation of a cDNA clone derived from a blood-borne non-A, non-B viral hepatitis genome. Science. 1989;244(4902):359-362.

2. Kuo G, Choo QL, Alter HJ, et al. An assay for circulating antibodies to a major etiologic virus of human non-A, non-B hepatitis. Science. 1989;244(4902):362-364.

3. Simmonds P. Genetic diversity and evolution of hepatitis $\mathrm{C}$ virus 15 years on. $J$ Gen Virol. 2004;85(Pt 11):3173-3188.

4. Williams R. Global challenges in liver disease. Hepatology. 2006;44(3):521-526.

5. Slowik MK, Jhaveri R. Hepatitis B and C viruses in infants and young children. Semin Pediatr Infect Dis. 2005;16(4):296-305.

6. Committee on Infectious Diseases. American Academy of Pediatrics: hepatitis C virus infection. Pediatrics. 1998;101(3 Pt 1):481-485.

7. Romanò L, Azara A, Chiaramonte M, et al. Low prevalence of anti-HCV antibody among Italian children. Infection. 1994;22(5):350-352.

8. Jonas MM, Robertson LM, Middleman AB. Low prevalence of antibody to hepatitis $\mathrm{C}$ virus in an urban adolescent population. $J$ Pediatr. 1997;131(2):314-316.

9. Davaalkham D, Ojima T, Nymadawa P, et al. Prevalence and risk factors for hepatitis $\mathrm{C}$ virus infection in Mongolian children: findings from a nationwide survey. J Med Virol. 2006;78(4):466-472.

10. Tanaka E, Kiyosawa K, Sodeyama T, et al. Prevalence of antibody to hepatitis $\mathrm{C}$ virus in Japanese schoolchildren: comparison with adult blood donors. Am J Trop Med Hyg. 1992;46(4):460-464.

11. al-Faleh FZ, Ayoola EA, al-Jeffry M, et al. Prevalence of antibody to hepatitis C virus among Saudi Arabian children: a community-based study. Hepatology. 1991;14(2):215-218.

12. el-Nanawy AA, el Azzouni OF, Soliman AT, et al. Prevalence of hepatitis-C antibody seropositivity in healthy Egyptian children and four high risk groups. J Trop Pediatr. 1995;41(6):341-343.

13. Jhaveri R, Grant W, Kauf TL, et al. The burden of hepatitis C virus infection in children: estimated direct medical costs over a 10-year period. J Pediatr. 2006;148(3):353-358.

14. Bortolotti F, Resti M, Giacchino R, et al. Changing epidemiologic pattern of chronic hepatitis $\mathrm{C}$ virus infection in Italian children. J Pediatr. 1998;133(3):378-381. 
15. Bortolotti F, Iorio R, Resti M, et al. An epidemiological survey of hepatitis C virus infection in Italian children in the decade 1990-1999. J Pediatr Gastroenterol Nutr. 2001;32(5):562-566.

16. Bortolotti F, Iorio R, Resti M, et al. Epidemiological profile of 806 Italian children with hepatitis $\mathrm{C}$ virus infection over a 15 -year period. J Hepatol. 2007;46(5):783-790.

17. Locasciulli A, Bacigalupo A, Vanlint MT, et al. Hepatitis C virus infection in patients undergoing allogeneic bone marrow transplantation. Transplantation. 1991;52(2):315-318.

18. Jonas MM, Zilleruelo GE, LaRue SI, et al. Hepatitis C infection in a pediatric dialysis population. Pediatrics. 1992;89(4 Pt 2):707-709.

19. Indolfi $G$, Resti M. Perinatal transmission of hepatitis $C$ virus infection. J Med Virol. 2009;81(5):836-843.

20. Resti M, Azzari C, Mannelli F, et al. Mother to child transmission of hepatitis $\mathrm{C}$ virus: prospective study of risk factors and timing of infection in children born to women seronegative for HIV-1. Tuscany Study Group on Hepatitis C Virus Infection. BMJ. 1998;317(7156):437-441.

21. Resti M, Bortolotti F, Vajro P, et al. Guidelines for the screening and follow-up of infants born to anti-HCV positive mothers. Dig Liver Dis. 2003;35(7):453-457.

22. Lin HH, Kao JH, Hsu HY, et al. Possible role of high-titer maternal viremia in perinatal transmission of hepatitis C virus. J Infect Dis. 1994; 169(3):638-641.

23. Ohto H, Terazawa S, Sasaki N, et al. Transmission of hepatitis C virus from mothers to infants. The Vertical Transmission of Hepatitis C Virus Collaborative Study Group. N Engl J Med. 1994;330(11):744-750.

24. Matsubara T, Sumazaki R, Takita H. Mother-to-infant transmission of hepatitis C virus: a prospective study. Eur J Pediatr. 1995;154(12): 973-978.

25. Moriya T, Sasaki F, Mizui M, et al. Transmission of hepatitis C virus from mothers to infants: its frequency and risk factors revisited. Biomed Pharmacother. 1995;49(2):59-64.

26. Okamoto M, Nagata I, Murakami J, et al. Prospective reevaluation of risk factors in mother-to-child transmission of hepatitis $\mathrm{C}$ virus: high virus load, vaginal delivery, and negative anti-NS4 antibody. $J$ Infect Dis. 2000;182(5):1511-1514.

27. Ceci O, Margiotta M, Marello F, et al. Vertical transmission of hepatitis $\mathrm{C}$ virus in a cohort of 2,447 HIV-seronegative pregnant women a 24-month prospective study. J Pediatr Gastroenterol Nutr. 2000; 33(5):570-575.

28. Conte D, Fraquelli M, Prati D, et al. Prevalence and clinical course of chronic hepatitis $\mathrm{C}$ virus (HCV) infection and rate of $\mathrm{HCV}$ vertical transmission in a cohort of 15,250 pregnant women. Hepatology. 2000;31(3):751-755.

29. Mast EE, Hwang LY, Seto DS, et al. Risk factors for perinatal transmission of hepatitis $\mathrm{C}$ virus (HCV) and the natural history of HCV infection acquired in infancy. $J$ Infect Dis. 2005;192(11):1880-1889.

30. Azzari C, Resti M, Moriondo M, et al. Vertical transmission of HCV is related to maternal peripheral blood mononuclear cell infection. Blood. 2000;96(6):2045-2048.

31. Azzari C, Indolfi G, Betti L, et al. Vertical hepatitis C virus transmission is not related to mother-child class-1 HLA concordance. Int J Immunopathol Pharmacol. 2007;20(4):827-831.

32. Spencer JD, Latt N, Beeby PJ, et al. Transmission of hepatitis C virus to infants of human immunodeficiency virus-negative intravenous drug-using mothers: rate of infection and assessment of risk factors for transmission. J Viral Hepat. 1997;4(6):395-409.

33. European Paediatric Hepatitis C Virus Network. A significant sex but not elective cesarean section - effect on mother-to-child transmission of hepatitis C virus infection. J Infect Dis. 2005;192(11): 1872-1879.

34. Steininger C, Kundi M, Jatzko G, et al. Increased risk of mother-to-infant transmission of hepatitis $\mathrm{C}$ virus by intrapartum infantile exposure to maternal blood. J Infect Dis. 2003;187(3):345-351.

35. Gibb DM, Goodall RL, Dunn DT, et al. Mother-to-child transmission of hepatitis $\mathrm{C}$ virus: evidence for preventable peripartum transmission. Lancet. 2000;356(9233):904-907.
36. Resti M, Azzari C, Lega L, et al. Mother-to-infant transmission of hepatitis C virus. Acta Paediatr. 1995;84(3):251-255.

37. Indolfi G, Bartolini E, Azzari C, et al. Intrafamilial transmission of hepatitis $\mathrm{C}$ virus: infection of the father predicts the risk of perinatal transmission. J Med Virol. 2008;80(11):1907-1911.

38. European Paediatric Hepatitis C Virus Network. Effects of mode of delivery and infant feeding on the risk of mother-to-child transmission of hepatitis C virus. European Paediatric Hepatitis C Virus Network. BJOG. 2001;108(4):371-377.

39. Tajiri H, Miyoshi Y, Funada S, et al. Prospective study of mother-toinfant transmission of hepatitis C virus. Pediatr Infect Dis J. 2001;20(1): 10-14.

40. Dal Molin G, D’Agaro P, Ansaldi F, et al. Mother-to-infant transmission of hepatitis $\mathrm{C}$ virus: rate of infection and assessment of viral load and IgM anti-HCV as risk factors. J Med Virol. 2002;67(2):137-142.

41. Resti M, Azzari C, Galli L, et al. Maternal drug use is a preeminent risk factor for mother-to-child hepatitis $\mathrm{C}$ virus transmission: results from a multicenter study of 1372 mother-infant pairs. J Infect Dis. 2002 ; 185(5):567-572.

42. Resti M, Bortolotti F, Azzari C, et al. Transmission of hepatitis C virus from infected mother to offspring during subsequent pregnancies. J Pediatr Gastroenterol Nutr. 2000;30(5):491-493.

43. Azzari C, Moriondo M, Indolfi G, et al. Higher risk of hepatitis $\mathrm{C}$ virus perinatal transmission from drug user mothers is mediated by peripheral blood mononuclear cell infection. J Med Virol. 2008;80(1): 65-71.

44. Zanetti AR, Tanzi E, Newell ML. Mother-to-infant transmission of hepatitis C virus. J Hepatol. 1999;31 Suppl 1:96-100.

45. Indolfi G, Azzari C, Moriondo M, et al. Alanine transaminase levels in the year before pregnancy predict the risk of hepatitis $\mathrm{C}$ virus vertical transmission. J Med Virol. 2006;78(7):911-914.

46. European Paediatric Hepatitis C Virus Network. Three broad modalities in the natural history of vertically acquired hepatitis $\mathrm{C}$ virus infection. Clin Infect Dis. 2005;41(1):45-51.

47. Resti M, Jara P, Hierro L, et al. Clinical features and progression of perinatally acquired hepatitis C virus infection. J Med Virol. 2003;70(3): 373-377.

48. Bortolotti F, Verucchi G, Cammà C, et al. Long-term course of chronic hepatitis $\mathrm{C}$ in children: from viral clearance to end-stage liver disease. Gastroenterology. 2008;134(7):1900-1907.

49. Bortolotti F, Resti M, Marcellini M, et al. Hepatitis C virus (HCV) genotypes in 373 Italian children with HCV infection: changing distribution and correlation with clinical features and outcome. Gut. 2005;54(6): 852-857.

50. Jara P, Resti M, Hierro L, et al. Chronic hepatitis C virus infection in childhood: clinical patterns and evolution in 224 white children. Clin Infect Dis. 2003;36(3):275-280.

51. Posthouwer D, Fischer K, van Erpecum KJ, et al. The natural history of childhood-acquired hepatitis $\mathrm{C}$ infection in patients with inherited bleeding disorders. Transfusion. 2006;46(8):1360-1366.

52. Mohan P, Colvin C, Glymph C, et al. Clinical spectrum and histopathologic features of chronic hepatitis $\mathrm{C}$ infection in children. $J$ Pediatr. 2007;150(2):168-174.

53. Birnbaum AH, Shneider BL, Moy L. Hepatitis C in children. N Engl J Med. 2000;342(4):290-291.

54. Rumbo C, Fawaz RL, Emre SH, et al. Hepatitis C in children: a quaternary referral center perspective. J Pediatr Gastroenterol Nutr. 2006; 43(2):209-216.

55. Zancan L, Strafella MS, Brugiolo A, et al. Chronic hepatitis C virus infection in childhood and early cirrhosis: it is possible? J Pediatr Gastroenterol Nutr. 2000;30(3):350-351.

56. Guido M, Rugge M, Jara P, et al. Chronic hepatitis C in children: the pathological and clinical spectrum. Gastroenterology. 1998;115(6): 1525-1529.

57. Badizadegan K, Jonas MM, Ott MJ, et al. Histopathology of the liver in children with chronic hepatitis C viral infection. Hepatology. 1998; 28(5):1416-1423. 
58. Bortolotti F, Muratori L, Jara P, et al. Hepatitis C virus infection associated with liver-kidney microsomal antibody type 1 (LKM1) autoantibodies in children. J Pediatr. 2003;142(2):185-190.

59. Adinolfi LE, Gambardella M, Andreana A, et al. Steatosis accelerates the progression of liver damage of chronic hepatitis $\mathrm{C}$ patients and correlates with specific HCV genotype and visceral obesity. Hepatology. 2001;33(6):1358-1364.

60. Fartoux L, Chazouillères O, Wendum D, et al. Impact of steatosis on progression of fibrosis in patients with mild hepatitis C. Hepatology. 2005;41(1):82-87.

61. Patton HM, Patel K, Behling C, et al. The impact of steatosis on disease progression and early and sustained treatment response in chronic hepatitis C patients. $J$ Hepatol. 2004;40(3):484-490.

62. Giannattasio A, Spagnuolo MI, Sepe A, et al. Is HCV infection associated with liver steatosis also in children? J Hepatol. 2006;45(3):350-354.

63. Gerotto M, Resti M, Dal Pero F, et al. Evolution of hepatitis C virus quasispecies in children with chronic hepatitis C. Infection. 2006;34(2):62-65.

64. Law MG, Dore GJ, Bath N, et al. Modelling hepatitis $\mathrm{C}$ virus incidence, prevalence and long-term sequelae in Australia, 2001. Int J Epidemiol. 2003;32(5):717-724.

65. Foster GR, Goldin RD, Thomas HC. Chronic hepatitis C virus infection causes a significant reduction in quality of life in the absence of cirrhosis. Hepatology. 1998;27(1):209-212.

66. Bonkovsky HL, Woolley JM. Reduction of health-related quality of life in chronic hepatitis $\mathrm{C}$ and improvement with interferon therapy. The Consensus Interferon Study Group. Hepatology. 1999;29(1): 264-270.

67. Koff RS. Impaired health-related quality of life in chronic hepatitis C: the how, but not the why. Hepatology. 1999;29(1):277-279.

68. Nydegger A, Srivastava A, Wake M, et al. Health-related quality of life in children with hepatitis $\mathrm{C}$ acquired in the first year of life. $J$ Gastroenterol Hepatol. 2008;23(2):226-230.

69. Rodrigue JR, Balistreri W, Haber B, et al. Impact of hepatitis C virus infection on children and their caregivers: quality of life, cognitive, and emotional outcomes. J Pediatr Gastroenterol Nutr. 2009;48(3): 341-347.

70. Ghany MG, Strader DB, Thomas DL, et al. Diagnosis, management, and treatment of hepatitis C: an update. Hepatology. 2009;49(4): 1335-1374.
71. Palumbo E. Treatment for chronic hepatitis $\mathrm{C}$ in children: a review. Am J Ther. 2009;16(5):446-450.

72. Wirth S, Pieper-Boustani H, Lang T, et al. Peginterferon alfa-2b plus ribavirin treatment in children and adolescents with chronic hepatitis $\mathrm{C}$. Hepatology. 2005;41(5):1013-1018.

73. Jara P, Hierro L, de la Vega A, et al. Efficacy and safety of peginterferonalpha $2 \mathrm{~b}$ and ribavirin combination therapy in children with chronic hepatitis C infection. Pediatr Infect Dis J. 2008;27(2):142-148.

74. Wirth S, Ribes-Koninckx C, Calzado MA, et al. High sustained virologic response rates in children with chronic hepatitis $\mathrm{C}$ receiving peginterferon alfa-2b plus ribavirin. J Hepatol. 2010;52(4):501-507.

75. Sokal EM, Bourgois A, Stéphenne X, et al. Peginterferon alfa-2a plus ribavirin for chronic hepatitis $\mathrm{C}$ virus infection in children and adolescents. J Hepatol. 2010;52(6):827-831.

76. Schwarz KB, Gonzalez-Peralta RP, Murray KF, et al. Peginterferon with or without ribavirin for chronic hepatitis $\mathrm{C}$ in children and adolescents: final results of the Peds-C trial. Hepatology. 2008;48:418A [Abst. 242].

77. Baker RD, Dee D, Baker SS. Response to pegylated interferon alpha-2b and ribavirin in children with chronic hepatitis C. J Clin Gastroenterol. 2007;41(1):111-114

78. Tajiri $\mathrm{H}$, Inui A, Kiyohara $\mathrm{Y}$, et al. Peginterferon alpha-2b and ribavirin for the treatment of chronic hepatitis $\mathrm{C}$ in Japanese pediatric and young adult patients: a survey of the Japan Society of Pediatric Hepatology. Eur J Gastroenterol Hepatol. 2009;21(11):1256-1260.

79. Kowala-Piaskowska A, Słuzewski W, Figlerowicz M, et al. Early virological response in children with chronic hepatitis $\mathrm{C}$ treated with pegylated interferon and ribavirin. Infection. 2007;35(3):175-179.

80. Jara P, Hierro L. Treatment of hepatitis C in children. Expert Rev Gastroenterol Hepatol. 2010;4(1):51-61.

81. Al Ali J, Owayed S, Al-Qabandi W, et al. Pegylated interferon alfa-2b plus ribavirin for the treatment of chronic hepatitis $\mathrm{C}$ genotype 4 in adolescents. Ann Hepatol. 2010;9(2):156-160.

82. Indolfi G, Stagi S, Bartolini E, et al. Thyroid function and anti-thyroid autoantibodies in untreated children with vertically acquired chronic hepatitis C virus infection. Clin Endocrinol (Oxf). 2008;68(1):117-121.

83. Narkewicz MR, Rosenthal P, Schwarz KB, et al. Ophthalmologic complications in children with chronic hepatitis $\mathrm{C}$ treated with pegylated interferon. J Pediatr Gastroenterol Nutr. 2010. Epub ahead of print.
Adolescent Health, Medicine and Therapeutics

\section{Publish your work in this journal}

Adolescent Health, Medicine and Therapeutics is an international, peer-reviewed, open access journal focusing on health, pathology, and treatment issues specific to the adolescent age group. All aspects of health maintenance, preventative measures and disease treatment interventions are addressed within the journal and practitioners from

\section{Dovepress}

all disciplines are invited to submit their work as well as healthcare researchers and patient support groups.. The manuscript management system is completely online and includes a very quick and fair peerreview system. Visit http://www.dovepress.com/testimonials.php to read real quotes from published authors. 